\title{
Effect of Different Saw Dust Substrates on the Growth and Yield of Oyster Mushroom (Pleurotus ostreatus)
}

\author{
Debu Kumar Bhattacharjya ${ }^{1}$, Ratan Kumar Paul ${ }^{2}$, Md. Nuruddin Miah ${ }^{1}$, Kamal \\ Uddin Ahmed ${ }^{1 *}$ \\ ${ }^{I}$ Department of Biochemistry, Sher-e-Bangla Agricultural University, Dhaka, Bangladesh \\ ${ }^{2}$ Department of Chemistry, Bangladesh University of Engineering \& Technology, Dhaka, Bangladesh
}

\begin{abstract}
Cultivation of Pleurotus ostreatus on different saw dust substrates such as Ficus carica (Fig tree, $\boldsymbol{T}_{2}$ ), Albizia saman (Rain Tree, $\boldsymbol{T}_{3}$ ), Swietenia mahagoni (Mahogany tree, $\boldsymbol{T}_{4}$ ), Leucaena leucocephala (Ipil ipil tree, $\boldsymbol{T}_{5}$ ), Eucalyptus globulus (Eucalyptus tree, $\boldsymbol{T}_{6}$ ) and mixture of all five tree sawdust $\left(\boldsymbol{T}_{1}\right)$ supplemented with $30 \%$ wheat bran and $1 \%$ lime as basal substrates were investigated. The effects of various saw dust substrates comparative growth and yield of performance oyster mushroom were analyzed. The highest mycelium running rate $\left(0.70 \mathrm{~cm} /\right.$ day) and the lowest time from primordial initiation to harvest (3.33 days), were obtained in $\boldsymbol{T}_{\boldsymbol{4}}$. The highest time from stimulation to primordial initiation (8.00 days) were found in $\boldsymbol{T}_{\mathbf{l}}$. The highest biological yield (373.4 g/packet), economic yield (371.8 g/packet), dry yield (37.16 g/packet), biological efficiency (213.2\%), benefit cost ratio (5.62), the highest average number of primordia/packet (226.3), the highest average number of fruiting body/packet (122.3), the highest average weight of individual fruiting body (4.45 g) and the highest average number of effective fruiting body/packet (21.33) were obtained in $\boldsymbol{T}_{3}$. Among all aspects, $\boldsymbol{T}_{3}$ was found as a best substrate with biological yield (373.4 g/packet) and BE (213.2\%) followed by $\boldsymbol{T}_{1}, \boldsymbol{T}_{4}, \boldsymbol{T}_{6}, \boldsymbol{T}_{5}, \boldsymbol{T}_{2}$ for the production of mushroom
\end{abstract}

Keywords: Growth, Sawdust, Spawn, Substrates, Pleurotus ostreatus, Wheat bran, Yield

\section{INTRODUCTION}

Mushrooms are one kind of edible fungi belonging to the genus Pleurotus under the class Basidiomycetes. Oyster mushroom (Pleurotus ostreatus) is an edible mushroom having excellent flavor and taste. Pleurotus species are popular and widely cultivated throughout the world mostly in Asia and Europe owing to their simple and low cost production technology and higher biological efficiency [1]. Cultivation of oyster mushroom has increased tremendously throughout the world because of their abilities to grow at a wide range of temperature and harvested all over the year [2]. Pleurotus have the ability to excrete hydrolyzing and oxidizing enzymes [3] which have capable of utilizing complex organic compounds that occurred agricultural wastes and industrial by-products [4] with broad adaptability varied agro-climatic conditions [5]. Pleurotus ostreatus demands few environmental controls, and their fruiting bodies are not often attacked by diseases and pests, and they can be cultivated in a simple and economic way [6]. It requires a short growth time in comparison to other edible mushrooms [7]. Mushrooms require carbon, nitrogen and inorganic compounds as their nutritional sources, the main nutrients are less nitrogen and more carbon congaing substrate such as most organic matters containing cellulose, hemicellulose and lignin can be used as mushroom substrate (i. e. rice and wheat straw, cottonseed hulls, corncob, sugarcane baggase, sawdust, waste paper, leaves, and so on) which supports the growth, development and fruiting of mushroom [8]. The growths of diverse type of mushrooms require different type of substrates and availability of varied type of materials may dictate which type is used [9]. Large quantity of freely available sawdust of different trees offers a potential substrate source for mushroom cultivation in the tropics [10]. Mushroom cultivation has a special relevance to Bangladesh, because sawdust and other materials are available to the farmers. In India, sawdust is the most popular basal ingredient used in substrates to grow shiitake mushroom compare to the wheat straw and rice or wheat bran [11-15].

In general edible mushrooms are low in fat and calories, rich in vitamins $\mathrm{B}, \mathrm{D}, \mathrm{K}$ and sometimes vitamins $\mathrm{A}$ and $\mathrm{C}$ [16], contain more protein than any other food of plant origin and are also a good source of mineral nutrients [17]. Malnutrition is a problem in developing third world countries. Mushrooms with their flavor, texture, nutritional value and high productivity per unit area have been identified as an excellent food source to alleviate malnutrition in developing countries [18]. Currently, high biofuel prices have caused an increase in food prices and food scarcity in many countries (World Bank, 2008). To alleviate hunger and malnutrition in a world of rising food prices, cultivation of mushrooms is a very reliable and profitable option. Oyster mushroom cultivation can play an important role in managing organic wastes whose disposal has become a problem [19]. These wastes can be recycled into food and environment may be less endangered by pollution [20]. Strengthening mushroom production sector could be essential in order to enable the rural economy to keep 
its vibrancy and development, increasing and diversifying business and employment opportunities in the rural areas, and providing income opportunities of small family farms. Furthermore, the use of these residues in bioprocesses may be one of the solutions to bioconversion of inedible biomass residues into nutritious protein rich food in the form of edible mushrooms [21]. Apart from food value, its medicinal value for diabetics and in cancer therapy has been emphasized [22]. Many of mushrooms pose a range of metabolites of intense interest to pharmaceutical e.g. antitumour, antigenotoxic, antioxidant, anti-inflammatory, anti-hypertensive, antiplateletaggregating, antihyperglycaemic, antimicrobial, antiviral activities and food industries [23].

The present experiment was undertaken to evaluate influence of locally available substrates containing sawdust of different trees with wheat ban and $1 \%$ lime on growth and yield of Pleurotus ostreatus mushroom. Those experiments were also to find the best sawdust among others as substrate for effective cultivation of oyster mushroom.

\subsection{Materials and Measurement}

\section{MATERIAL AND METHODS}

The experiment was carried out at the Mushroom Culture House $(\mathrm{MCH})$, Biochemistry laboratory of the Department of Biochemistry, Sher-e-Bangla Agricultural University, Dhaka, Bangladesh and National Mushroom Development and Extension Center (NAMDEC) laboratory, Savar, Dhaka, Bangladesh during July' 2012 to December' 2012. Fruiting body of oyster mushroom was collected from NAMDEC, Saver, Dhaka, Bangladesh. Oyster mushrooms (Pleurotus ostreatus) are characterized by the rapidity of the mycelial growth and high saprophytic colonization activity on cellulosic substrates. The sample was weighted by electric balance (KEY: JY-2003; China) and heated in a muffle furnace (Nebertherm: Mod-L9/11/c6; Germany).

\subsection{Sterilization Procedure}

In the laboratory, all of the apparatuses, equipment, metallic instruments, glassware and culture media were sterilized in the autoclave at $121^{\circ} \mathrm{C}$ about 1 hour at $1.5 \mathrm{~kg} / \mathrm{cm}^{2}$ pressure strictly for maintaining sterility. The culture room of the laboratory was cleaned by gently washing with detergent followed by $70 \%$ ethyl alcohol regularly. Before inoculation, laminar airflow cabinet was sterilized using ultra violet light for 30 minute keeping blower active. All inoculation measures were carried out in the laminar airflow cabinet to avoid contamination. The cabinet was exposed on the UV light for 30 minutes before use. All the instruments and equipment used were sterilized with alcohol before use.

\subsection{Production of Oyster Mushroom (P. ostreatus) \\ 2.3.1. Preparation of PDA Media}

At first, $250 \mathrm{~g}$ potatoes were washed, peeled and sliced to prepare $1000 \mathrm{~mL}$ PDA media. Then peeled and sliced potatoes were boiled in water to make them soft and also filtered through a cheese cloth and further water was added to get $1000 \mathrm{~mL}$ media. After adding $18 \mathrm{~g}$ agar and $20 \mathrm{~g}$ dextrose, it was heated and stirred for about 45 minutes. Then $10 \mathrm{~mL}$ media was taken into each of test tube and mouths of the test tubes were plugged with cotton and brown paper. After that all the test tubes were sterilized in an autoclave for 20 minutes at $121^{\circ} \mathrm{C}$ and $1.5 \mathrm{~kg} / \mathrm{cm}^{2}$ and kept in slanting position for having maximum space for the organism in pure culture to proliferate.

\subsubsection{Tissue Culture}

To obtain pure culture, a small piece of tissue was collected from the fruiting body of mushroom, Pleurotus ostreatus and placed on the sterilized PDA medium under aseptic condition in a laminar air flow cabinet. It was then kept for 7-10 days in an incubator under $25^{\circ} \mathrm{C}$ for sufficient mycelial growth. These pure cultures were used for the entire experiment.

\subsubsection{Preparation of Mother Spawn}

Mother culture substrate was prepared by using sawdust. Sawdust was sieved and sun dried. The mother culture substrate was prepared by sawdust and wheat bran in $2: 1$ ratio with $0.1 \%$ calcium carbonate [24]. Then it was mixed thoroughly with hands and maintained 55\% moisture content by adding sufficient water. Then $200 \mathrm{~g}$ of mixture was packed tightly $18 \times 25 \mathrm{~cm}$ polypropylene bags. Each of the bags was prepared by using bamboo neck and plugged the neck with cotton and covered with brown paper placing rubber band to hold it tightly in place. The packets were sterilized for 1 hour at $121^{\circ} \mathrm{C}$ with $1.5 \mathrm{~kg} / \mathrm{cm}^{2}$ pressures in an autoclave and kept them for cooling. Then inoculums from pure culture were placed aseptically to the mother spawn packets. The packets after inoculation were again plugged with cotton and were kept at $20-22^{\circ} \mathrm{C}$ for spawn run. The whole packet containing substrate became white due to fungal mycelia proliferation within 15-20 days and thus ready for spawning the substrate [25]. 


\subsubsection{Preparation of Spawn Packets}

Spawn packets using different saw dust (individual five trees as $\mathbf{T}_{\mathbf{2}}, \mathbf{T}_{\mathbf{3}}, \mathbf{T}_{\mathbf{4}}, \mathbf{T}_{\mathbf{5}}, \mathbf{T}_{\mathbf{6}}$ and mixture of five trees as $\mathbf{T}_{\mathbf{1}}$ ), wheat bran and $\mathrm{CaCO}_{3}$ in ratio 69:30:1 respectively. The mixed substrates were filled into $10 \times 12$ inch polypropylene bag. The spawn packets preparation, sterilization, inoculation and incubation were done using the method described by Sarker et al. [26, 27]. The weight of each spawn packet was $500 \mathrm{~g}$. Moisture was measured by using the moisture meter and adjusted the moisture content at $65 \%$. Therefore the packets were sterilized about $1 \mathrm{~h}$ and then these were kept for cooling. After cooling, $5 \mathrm{~g}$ mother spawn were inoculated into the packets in the laminar airflow cabinet and were kept at $20-22^{\circ} \mathrm{C}$ temperature until the packets become white with the mushroom mycelium. After completion of the mycelium running the rubber band, brown paper, cotton plug and bamboo neck of the mouth of spawn packet were removed and the mouth was wrapped tightly with rubber band. Than this spawn packets were transferred to the culture house.

\subsubsection{Cultivation of Spawn Packet}

Two ends, opposite to each other of the upper position of plastic bag were cut in "D" shape with a blade and opened by removing the plastic sheet after which the opened surface of substrate was scraped slightly with a tea spoon for removing the thin whitish mycelial layer. Then the spawn packets were soaked in water for 15 minutes and invested to remove excess water for another 15 minutes. The packets of each type were placed separately on the floor of culture room and covered with newspaper. The moisture of the culture room was maintained $80-85 \%$ relative humidity by spraying water 3 times a day. The light around 300-500 lux and ventilation of culture house was maintained uniformly. The temperature of culture house was maintained 22$25^{\circ} \mathrm{C}$. The first primordia appeared 3-5 days after scribing depending upon the type of substrate. The harvesting time also varied depending upon the type of substrate $[\mathbf{2 6}, \mathbf{2 7}]$.

\subsubsection{Harvesting of Mushroom}

Oyster mushrooms matured within 2-3 days after primordia initiation. The matured fruiting body was identified by cural margin of the cap, as described by Ruhul Amin et al. [28]. Mushrooms were harvested by twisting to uproot from the base. Mushrooms were harvested 3 times from a packet. After completing the first harvest again the packets were scraped at the place where the ' $\mathrm{D}$ ' shaped cut had been done and were soaked in a bucket for five minutes and then placed in the culture house and water was sprayed regularly. The primordia appeared 9-10 days after first harvest and 7-8 days after second harvest. Water spraying was continued until the mushrooms were ready to be harvested.

\subsection{Data Collection}

Data were collecting on the following parameters

Mycelial Growth (\%): Mycelial growth was counted by taking the full packet as a full unit and generally the data was taken at every two days intervals.

Mycelium Running Rate in Spawn Packet (cm): Mycelium running rate (MRR) for each type of substrate was measured after the mycelium colony cross the shoulder of the packet. The linear length was measured at different places of packet [27].

$$
\begin{aligned}
& \text { MRR }=\frac{\mathbf{L}}{\mathbf{N}} \mathbf{c m} / \mathbf{d a y} \\
& \text { Where, } \\
& \qquad \begin{array}{l}
\text { L } \\
\mathrm{N}
\end{array}=\text { Average length of mycelium running for different places }(\mathrm{cm}) \\
&
\end{aligned}
$$

Days Required for Completing Mycelium Running: Days required from inoculation to completion of mycelium running were measured.

Time from Stimulation to Primordia Initiation (days): Time required from stimulation to primordia initiation (days) were recorded.

Time from Primordial Initiation to Harvest (days): Time required from primordial initiation to harvest (days) were recorded.

Average Number of Primordial/Packet: Number of primordial/packet was recorded.

Average Number of fruiting Body/Packet: Number of well-developed fruiting body was recorded. Dry and pinheaded fruiting bodies were discarded but tiny fruiting bodies were included in counting.

Average Number of Effective Fruiting Body/Packet: Number of very well-developed fruiting body was recorded. Tiny fruiting bodies were discarded from counting.

Average Weight of Individual Fruiting Body/Packet: Average weight of individual fruiting body was calculated by dividing the total weight of fruiting body per packet by the total number of fruiting body per packet.

Dimension of Fruiting Body (pileus and stripe): Diameter of pileus (cm), thickness of pileus (cm) and length of stripe $(\mathrm{cm})$ of three randomly selected fruiting bodies was measured using a slide calipers 
Biological Yield $(\mathrm{g})$ : Biological yield per $500 \mathrm{~g}$ packet was measured by weighing the whole cluster of fruiting body without removing the lower hard and dirty portion.

Economic Yield: Economic yield per $500 \mathrm{~g}$ packet was recorded by weighing all the fruiting bodies in a packet after removing the lower hard and dirty portion.

Dry Yield: About $50 \mathrm{~g}$ of randomly selected mushroom sample was taken in a paper envelop and was weighed correctly. The mushroom was oven dried at $72^{\circ} \mathrm{C}$ temperature for 24 hours and weighed again. The weight of blank envelop was subtracted from both the weight [27]. The dry yield was calculated using the following formula.

\section{Dry Yield (g/500g Packet) $=$ Economic Yield $\times \frac{\text { Oven Dry Weight of Sample }(g)}{\text { Fresh Weight of Sample }(\mathrm{g})}$}

Drying of Mushrooms: The collected fruiting bodies of the mushroom are transferred to the laboratory. Therefore data are collected on different parameter. After collection of the data the fruiting bodies are dried in the sun separately treatment wise. In the time of drying the stipe and the pileus are separated for better drying. Biological Efficiency: Biological efficiency was determined by the following formula [29].

$$
\text { Biological Efficiency }=\frac{\text { Total Biological Weight }(g)}{\text { Total Weight of Substrate used }(g)} \times 100
$$

Benefit Cost Ratio: The benefit cost ratio for different low cost substrate were computed based on present market price of mushroom and cost of different inputs in the markets [27].

\subsection{Effect on Mycelium Growth \\ Effect of Different Sawdust Substrates on Mycelium Running Rate in Spawn (cm)}

\section{RESULTS AND DISCUSSION}

Mycelium running rate per day (MRR) for each type of substrates was measured after the mycelium colony crossed the shoulder of the packet. The highest running rate was observed in $\mathbf{T}_{\mathbf{4}}(0.70 \mathrm{~cm})$ followed by $\mathbf{T}_{\mathbf{3}}(0.66 \mathrm{~cm})$ which was statically similar to $\mathbf{T}_{5}(0.62 \mathrm{~cm}), \mathbf{T}_{\mathbf{6}}(0.59 \mathrm{~cm})$ and $\mathbf{T}_{\mathbf{2}}(0.58 \mathrm{~cm})$ treatment and the lowest mycelium running rate of mycelium was observed in $\mathbf{T}_{\mathbf{1}}(0.54 \mathrm{~cm})$ as shown in Table 1 . The result of the present study corroborates with the study of previous workers (Khan et al., 2001; Kalita et al., 2001) [30, 31] they were reported that time taken for completion of spawn running may require to 17 days from 22 days by use of different substrates. Sarker et al. (2004) found that the mycelium running rate of oyster mushroom greatly influenced with the supplement of wheat brans in different levels [27]. Royse et al. (2002) found, as the spawn rate increased the number of days to production decreased [32]. The result of the present study is similar to the Bhuyan (2008) experiment result [33].

\section{Effect of Different Sawdust Substrates on Time from Stimulation to Primordia Initiation (Days)}

The time from stimulation to primordia initiation ranged from 6.0-8.0 days. The lowest time from stimulation to primordia initiation was observed in $\mathbf{T}_{\mathbf{3}}$ and $\mathbf{T}_{\mathbf{2}}$ (6.0 days). The highest time from stimulation to primordia initiation was observed in $\mathbf{T}_{\mathbf{1}}$ (8.0 days). Statically similar stimulation primodia initiation was shown in the treatment to $\mathbf{T}_{\mathbf{6}}$ ( 7.6 days), $\mathbf{T}_{\mathbf{4}}$ (7.33 days) and $\mathbf{T}_{\mathbf{5}}$ (6.67 days) treatments as shown in Table 1. The results varied with the findings of Patra and Pani (1995)[34] who found that oyster mushroom took 4-8 days for initiation of fruiting bodies but in the present study, it was ranged from 6.0-8.0 days. The difference among the findings may be due to the difference in cultural environment, substrates or the varieties.

\section{Effect of Different Sawdust Substrates on Time from Primordia Pnitiation to Harvest (Days)}

All the treatments were statistically similar but numerically vary to each other as shown in Table 1. Numerically the lowest time from primordia initiation to harvest was in the treatment $\mathbf{T}_{\mathbf{4}}$ (3.33 days) followed by $\mathbf{T}_{5}$ and $\mathbf{T}_{\mathbf{6}}$ (3.67 days) and the highest time from primordia initiation to harvest was observed in the treatment $\mathbf{T}_{\mathbf{1}}$ and $\mathbf{T}_{\mathbf{3}}$ (4.33 days) in Table 1. The findings of the present experiment are in conformity with Shah et al. (2004) who found that fruiting bodies of oyster mushroom became suitable for harvest within 3-6 day of primordia initiation in the spawn packet [9]. Khan et al. (2001) reported that after spawn running pinhead formation took 7-8 days and fruiting body formed after 3-5 days, sporocarps may be harvested after 10-12 days [30]. Dhoke et al. (2001) found significant effect of different agro-wastes on yield of oyster mushroom [35]. The days required for first picking varied from 11.25-12.00 and the final picking complete from 42.25-43.50 days depending on different substrates. 
Table 1. Effect of sawdust substrates on mycelial growth of oyster mushroom (P. ostreatus)

\begin{tabular}{cccc}
\hline Treatments & $\begin{array}{c}\text { Mycelium running rate in spawn } \\
\text { packet (cm) }\end{array}$ & $\begin{array}{c}\text { Time from stimulation to primordial } \\
\text { initiation (days) }\end{array}$ & $\begin{array}{c}\text { Time from primordia } \\
\text { initiation to harvest (days) }\end{array}$ \\
\hline $\mathrm{T}_{1}$ & $0.54 \mathrm{c}$ & $8.00 \mathrm{a}$ & $4.33 \mathrm{a}$ \\
$\mathrm{T}_{2}$ & $0.58 \mathrm{bc}$ & $6.00 \mathrm{~b}$ & $4.00 \mathrm{a}$ \\
$\mathrm{T}_{3}$ & $0.66 \mathrm{ab}$ & $6.00 \mathrm{~b}$ & $4.33 \mathrm{a}$ \\
$\mathrm{T}_{4}$ & $0.70 \mathrm{a}$ & $7.33 \mathrm{ab}$ & $3.33 \mathrm{a}$ \\
$\mathrm{T}_{5}$ & $0.62 \mathrm{abc}$ & $6.67 \mathrm{ab}$ & $3.67 \mathrm{a}$ \\
$\mathrm{T}_{6}$ & $0.59 \mathrm{bc}$ & $7.6 \mathrm{ab}$ & $3.67 \mathrm{a}$ \\
$\mathrm{CV}(\%)$ & $6.54 \%$ & $13.58 \%$ & $16.04 \%$ \\
$\operatorname{LSD}(\mathbf{0 . 0 5})$ & 0.081 & 1.72 & 1.14 \\
\hline
\end{tabular}

Means followed by same letter significantly different at $1 \%$ or $5 \%$ level of significance

\subsection{Effect on Yield Contributing Characters and Yield}

\section{Effect of Different Dawdust Substrates on Average No. of Primordia/Packet}

All the treatments were statistically similar but numerically vary to each other as shown in Table 2. Numerically the highest average number of primordia/packet was observed in the treatment $\mathbf{T}_{\mathbf{3}}(226.3)$ followed by $\mathbf{T}_{\mathbf{1}}(210.3)$ and $\mathbf{T}_{\mathbf{4}}(210.0)$ treatments and the lowest average number of primordia/packet was in the treatment $\mathbf{T}_{2}$ (196.3). Ahmed et al. (1998) reported significantly different number of primordia on different substrates [29]. Dey et al. (2006) found that the number of primordia and the average yield significantly varied with the substrates used in production of oyster mushroom [36]. Bhuyan (2008) found similar findings growing oyster mushroom on sawdust supplemented with different levels of cow dung [33].

\section{Effect of Different Sawdust Substrates on Average No. of Fruiting Body/Packet}

The highest average number of fruiting body/packet was observed in the treatment $\mathbf{T}_{\mathbf{3}}(122.3)$ and the lowest average number of fruiting body /packet was in the treatment $\mathbf{T}_{\mathbf{2}}(76.0)$ followed by $\mathbf{T}_{\mathbf{5}}(82.33)$. The other treatments were statistically and significantly varied over control in terms of average number of primordia/packet as shown in Table 2. Yoshida et al. (1993) reported that the number of fruiting bodies was lower, but increased when the substrates was mixed with different supplements [37]. Amin et al. (2007) reported that the number of primordia grown on different substrates differed significantly [24]. Sarker (2004) found that the number of primordia increased with the levels of supplement and continued up to a certain range [27]. Bhuyan (2008) in a same type of experiment found similar results [33].

\section{Effect of Different Sawdust Substrates on Average No. of Effective Fruiting Body/Packet}

Numerically the highest average number of effective fruiting body/packet was observed in the treatment $\mathbf{T}_{\mathbf{3}}$ (21.33) followed by $\mathbf{T}_{\mathbf{1}}$ (19.67) treatment and the lowest average number of effective fruiting body/packet was in the treatment $\mathbf{T}_{\mathbf{2}}$ (15.67). The other treatments differed significantly in terms of average number of primordia/packet as shown in Table 2. The findings of the present study matches with the study of Yoshida et al. (1993) who reported that the number of effective fruiting bodies was lower, but increased when the substrates was mixed with different supplements [37]. The comparative similar findings were also found by Ruhul Amin (2007) and Ahmed (1998) [24, 29].

\section{Effect of Different Sawdust Substrates on Average Weight of Individual Fruiting Body (g)}

Effect of different sawdust substrates had great effect on average weight of individual fruiting body. The average weight of individual fruiting body in different treatment ranged from 4.45-2.95 g. The highest average weight of individual fruiting body was observed in the treatment $\mathbf{T}_{\mathbf{3}}$ (4.45 g) followed by $\mathbf{T}_{\mathbf{1}}(4.30 \mathrm{~g})$ treatment and the lowest average weight of individual fruiting body was in the treatment $\mathbf{T}_{2}(2.95 \mathrm{~g})$ The other treatments varied significantly over control in terms of average weight of individual fruiting body as shown in Table 2. Sarker et al. (2007) reported the individual weigh of fruiting body ranged from 1.33-1.59 $\mathrm{g}$, which was more or less similar to this study [26]. Bhuyan (2008) found significant effect of supplementation on the weight of fruiting body but he found comparatively higher weight of individual fruiting body ranged from (5.02-7.01 $\mathrm{g}$ ), which may be due to environmental conditions or growing season [33].

\section{Effect of Different Sawdust Substrates on Average Length of Stripe}

The highest average length of stripe was observed in the treatment $\mathbf{T}_{\mathbf{4}}(1.63 \mathrm{~cm})$ followed by $\mathbf{T}_{\mathbf{1}}(1.3$ $\mathrm{cm}), \mathbf{T}_{\mathbf{2}}, \mathbf{T}_{\mathbf{3}}$, and $\mathbf{T}_{\mathbf{5}}(1.30 \mathrm{~cm})$ treatments and the lowest average length of stripe was in the treatment $\mathbf{T}_{\mathbf{6}}(1.17$ $\mathrm{cm})$. The other treatments differed significantly over control in terms of average weight of individual fruiting body as shown in Table 2. The findings of the present study were matched with the study of Sarker et al. (2007) 
and Habib (2005) they were reported that the stripe length of Pleorotus spp. on different substrate varied from $1.93-2.97 \mathrm{~cm}$ and the diameter ranged from $0.74-1.05 \mathrm{~cm}[\mathbf{2 6}, \mathbf{3 8}]$.

\section{Effect of Different Sawdust Substrates on Average Thickness of Pileus}

Effect of different sawdust substrates had great effect on average thickness of pileus. The average thickness of pileus in different treatment ranged from $0.90-0.70 \mathrm{~cm}$. All the treatments were statistically similar as shown in Table 2. The findings of the present study matches with the study of Habib et al. (2005) who found that the diameter of pileus ranged from $4.85-8.95 \mathrm{~cm}$ and thickness of the pileus ranged from $0.45-0.70 \mathrm{~cm}$ due to different substrates [38] and Sarker et al., 2007 reported that the thickness of pileus ranged from $0.50-0.80 \mathrm{~cm}$ in case oyster mushroom [26].

Table 2. Effect of sawdust substrates on mushroom yield attributes of oyster mushroom (P. ostreatus)

\begin{tabular}{ccccccc}
\hline Treatments & $\begin{array}{c}\text { Average No. of } \\
\text { primordia/packet }\end{array}$ & $\begin{array}{c}\text { Average No. } \\
\text { of fruiting } \\
\text { body/packet }\end{array}$ & $\begin{array}{c}\text { Average No. of } \\
\text { effective } \\
\text { fruiting } \\
\text { body/packet }\end{array}$ & $\begin{array}{c}\text { Average weight } \\
\text { of Individual } \\
\text { fruiting body }\end{array}$ & $\begin{array}{c}\text { Average } \\
\text { length of stripe } \\
\text { (cm/ stripe) }\end{array}$ & $\begin{array}{c}\text { Average } \\
\text { thickness of } \\
\text { pileus } \\
\text { (cm/pileus) }\end{array}$ \\
\hline$T_{1}$ & $210.3 \mathrm{a}$ & $106.7 \mathrm{ab}$ & $19.67 \mathrm{a}$ & $4.30 \mathrm{ab}$ & $1.33 \mathrm{ab}$ & $0.70 \mathrm{a}$ \\
$\mathrm{T}_{2}$ & $196.3 \mathrm{a}$ & $76.00 \mathrm{~b}$ & $15.67 \mathrm{a}$ & $2.95 \mathrm{~b}$ & $1.30 \mathrm{ab}$ & $0.80 \mathrm{a}$ \\
$\mathrm{T}_{3}$ & $226.3 \mathrm{a}$ & $122.3 \mathrm{a}$ & $21.33 \mathrm{a}$ & $4.45 \mathrm{a}$ & $1.30 \mathrm{ab}$ & $0.90 \mathrm{a}$ \\
$\mathrm{T}_{4}$ & $210.0 \mathrm{a}$ & $101.0 \mathrm{ab}$ & $17.33 \mathrm{a}$ & $3.87 \mathrm{ab}$ & $1.63 \mathrm{a}$ & $0.80 \mathrm{a}$ \\
$\mathrm{T}_{5}$ & $197.7 \mathrm{a}$ & $82.33 \mathrm{~b}$ & $16.33 \mathrm{a}$ & $3.34 \mathrm{ab}$ & $1.30 \mathrm{ab}$ & $0.70 \mathrm{a}$ \\
$\mathrm{T}_{6}$ & $207.7 \mathrm{a}$ & $93.0 \mathrm{ab}$ & $18.00 \mathrm{a}$ & $3.75 \mathrm{ab}$ & $1.17 \mathrm{~b}$ & $0.77 \mathrm{a}$ \\
$\mathrm{CV}(\%)$ & $8.60 \%$ & $22.60 \%$ & $19.39 \%$ & $20.08 \%$ & $16.68 \%$ & $16.21 \%$ \\
$\mathrm{LSD}(0.05)$ & 32.54 & 39.83 & 6.37 & 1.38 & 0.40 \\
\hline
\end{tabular}

Means followed by same letter significantly different at $1 \%$ or $5 \%$ level of significance

\subsection{Effect of Different Sawdust Substrates on Biological Yield, Economic Eield (g), Dry Yield, Biological Efficiency, Benefit Cost Ratio}

All the treatments were statistically similar but numerically vary to each other as shown in Table 3. Effect of different sawdust substrates had great effect on biological yield. Numerically the highest biological yield was counted under treatment $\mathbf{T}_{3}(373.4 \mathrm{~g} / \mathrm{packet})$ followed by $\mathbf{T}_{\mathbf{1}}(356.2 \mathrm{~g} / \mathrm{packet})$ treatment and the lowest biological yield was counted under $\mathbf{T}_{\mathbf{2}}(327.3 \mathrm{~g} / \mathrm{packet})$. The other treatments varied significantly as compared with control in terms of biological yield (Table 3). Chowdhury et al. (1998) examined the effects of adding different supplements to substrates for growing oyster mushrooms (Pleurotus sajor-caju) and found adding 5\% supplements gave the highest yield of oyster mushroom [39]. Baysal et al. (2003) found the highest yield of $P$. ostreatus with the substrate composed of $20 \%$ rice husk in weigh [10]. Ruhul Amin et al. (2007) found the highest biological yield 247.3g/packet [24]. He also found that the trend of economic yield corresponded with different supplements at different level.

Numerically the highest economic yield was recorded under treatment $\mathbf{T}_{\mathbf{3}}(371.8 \mathrm{~g} / \mathrm{packet})$ followed by $\mathbf{T}_{\mathbf{1}}$ (354.6 g/packet) treatment and the lowest economic yield was counted under $\mathbf{T}_{\mathbf{2}}$ (324.8 g/ packet). The other treatments varied significantly over control as shown in Table 3. Payapanon et al. (1994) mentioned that suitable amount of supplements added to rice straw medium maximized economic yield of oyster mushroom at optimum production cost. Sarker (2004) found appreciable variations in economic yield also observed at different levels of supplements under different substrate-supplement combinations [27]. Bhuyan (2008) observed that the yield of $P$. ostreatus responded with the levels of supplements used with sawdust and increased with the level of supplementation and declined thereafter [33].

The dry yield of the oyster mushroom, grown on different sawdust substrates responded significantly in terms of dry yield with supplement. Numerically the dry yield of mushroom was maximum under the treatment $\mathbf{T}_{\mathbf{3}}$ (37.16 g/ packet) followed by $\mathbf{T}_{\mathbf{1}}$ (35.46 g/packet) treatment and the lowest dry yield was counted under $\mathbf{T}_{\mathbf{2}}$ (32.48 g/ packet). The other treatments varied significantly over control (Table 3). The result of the present study corroborates with Ahmed (1998) who observed significant effects of various substrates on diameter and length of stalk also diameter and thickness of pileus [29]. He also found that lower diameter of pileus produced the lowest yield and concluded that the diameter of pileus increased the quality and yield of mushroom and highest dry yield from mango sawdust. Sarker et al. (2007) found the range of dry yield from 4.28-29.98, which was more or less similar to this study [26].

Numerically the highest biological efficiency of $213.2 \%$ was calculated in treatment $\mathbf{T}_{3}$ and the lowest biological efficiency of $187.0 \%$ was calculated from $\mathbf{T}_{\mathbf{2}}$ as shown in Table 3. The other treatments varied significantly over control. The present findings keep in with the findings of previous workers; Biswas et al. (1997) found supplementation of substrate promoted biological efficiency (125.75\%) [40]. Patrabansh and 
Madan (1997) reported the similar result in growing Pleurotus sajor-caju [41]. Kalita et al. (1997) observed biological efficiency for different substrates ranged from 35.2-60.9\% [31]. Obodai et al. (2003) found biological efficiency (BE) followed a pattern and ranged from 61.0-80.0\% [42].

The highest cost benefit ratio was calculated in treatment $\mathbf{T}_{\mathbf{3}}$ (5.62) and the lowest cost benefit ratio 4.87 was calculated from $\mathbf{T}_{2}$ followed by $\mathbf{T}_{\mathbf{4}} 5.24$. The other treatments differed significantly in terms of cost benefit ratio as shown in Table 3. Ahmed (1998) also observed the benefit cost ratio of 73.2, 23.78 and 16.23 in case of Pleurotus sajor-caju [29]. The cause of these variations between the results of this study might be due to consideration of other costs involved in the production of oyster mushroom or might be due to measuring system. Sarker et al, (2007) mentioned the performances of substrates were significantly differed based on benefit cost ratio. They reported the highest cost benefit ratio of 6.50 with wheat straw [26].

Table 3. Effect of sawdust substrates on yield of oyster mushroom (P. ostreatus)

\begin{tabular}{cccccc}
\hline Treatments & $\begin{array}{c}\text { Biological } \\
\text { yield }(\mathrm{g})\end{array}$ & $\begin{array}{c}\text { Economic yield } \\
(\mathrm{g})\end{array}$ & $\begin{array}{c}\text { Dry yield } \\
(\mathrm{g})\end{array}$ & $\begin{array}{c}\text { Biological } \\
\text { efficiency }(\%)\end{array}$ & Benefit cost ratio \\
\hline $\mathrm{T}_{1}$ & $356.2 \mathrm{a}$ & $354.6 \mathrm{a}$ & $35.46 \mathrm{a}$ & $203.5 \mathrm{a}$ & $5.32 \mathrm{ab}$ \\
$\mathrm{T}_{2}$ & $327.3 \mathrm{a}$ & $324.8 \mathrm{a}$ & $32.48 \mathrm{a}$ & $187.0 \mathrm{a}$ & $4.87 \mathrm{~b}$ \\
$\mathrm{~T}_{3}$ & $373.4 \mathrm{a}$ & $371.8 \mathrm{a}$ & $37.16 \mathrm{a}$ & $213.2 \mathrm{a}$ & $5.62 \mathrm{a}$ \\
$\mathrm{T}_{4}$ & $350.8 \mathrm{a}$ & $349.5 \mathrm{a}$ & $34.95 \mathrm{a}$ & $200.5 \mathrm{a}$ & $5.24 \mathrm{~b}$ \\
$\mathrm{~T}_{5}$ & $334.6 \mathrm{a}$ & $333.0 \mathrm{a}$ & $33.30 \mathrm{a}$ & $191.2 \mathrm{a}$ & $4.99 \mathrm{ab}$ \\
$\mathrm{T}_{6}$ & $349.2 \mathrm{a}$ & $347.8 \mathrm{a}$ & $34.81 \mathrm{a}$ & $199.5 \mathrm{a}$ & $5.22 \mathrm{ab}$ \\
$\mathrm{CV}(\%)$ & $7.42 \%$ & $7.47 \%$ & $7.45 \%$ & $7.42 \%$ & $7.47 \%$ \\
$\mathrm{LSD}_{(0.05)}$ & 47.06 & 47.15 & 4.703 & 26.90 & 0.707 \\
\hline
\end{tabular}

Means followed by same letter significantly different at $1 \%$ or $5 \%$ level of significance

\section{CORRELATION STUDY}

The highest average no of fruiting body was recorded under treatment $\mathbf{T}_{\mathbf{4}}$ (122.3) and the highest economic yield was recorded under treatment $\mathbf{T}_{3}(371.8 \mathrm{~g})$. The lowest average no of fruiting body was recorded under treatment $\mathbf{T}_{\mathbf{2}}$ (76.00) followed by $\mathbf{T}_{\mathbf{5}}$ (82.33) and lowest economic yield was under $\mathbf{T}_{\mathbf{2}}(324.8 \mathrm{~g})$ as shown in fig.1.

A significant and positive correlation between average number of effective fruiting body and biological yield was observed when different sawdust was supplemented with wheat bran. That could be expressed by the equation $\mathrm{y}=7.405 \mathrm{x}+214.8\left(\mathrm{R}^{2}=0.930^{* *}\right)$ where $\mathrm{y}=$ biological yield and $\mathrm{x}=$ average number of effective fruiting body. The $\mathrm{R}^{2}$ value indicated that $93 \%$ of biological yield of oyster mushroom ( $P$. ostreatus) was attributed to the average number of effective fruiting body (Fig. 2).

A significant and positive correlation between average number of primodial/packet and biological yield was observed when different sawdust was supplemented with wheat bran. That could be expressed by the equation $\mathrm{y}=1.485 \mathrm{x}+39.50\left(\mathrm{R}^{2}=0.969 * *\right)$ where $\mathrm{y}=$ biological yield and $\mathrm{x}=$ average number of primodial/packet. The $\mathrm{R}^{2}$ value indicated that $96.9 \%$ of biological yield of oyster mushroom ( $P$. ostreatus) was attributed to the average number of primodial/packet (Fig. 3).

A significant and positive correlation between average weight of individual fruiting body and economical yield was observed when different sawdust was supplemented with wheat bran. That could be expressed by the equation $\mathrm{y}=2815 \mathrm{x}+240.5\left(\mathrm{R}^{2}=0.933^{* *}\right)$ where $\mathrm{y}=$ economical yield and $\mathrm{x}=$ average weight of individual fruiting body. The $\mathrm{R}^{2}$ value indicated that $93.3 \%$ of economical yield of oyster mushroom $(P$. ostreatus) was attributed to the average weight of individual fruiting body (Fig. 4).
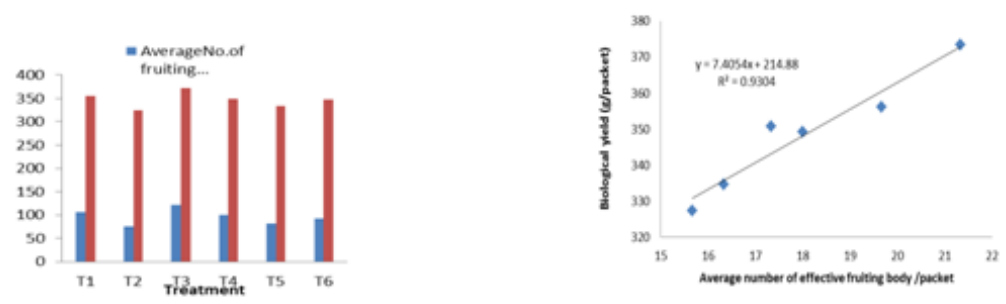

Fig. 1. Effect of different sawdust on relation between average no of fruiting body/packet and economic yield (g)
Fig. 2. Functional relationship between average numbers of effective fruiting body with biological yield as influenced by different sawdust substrates. 


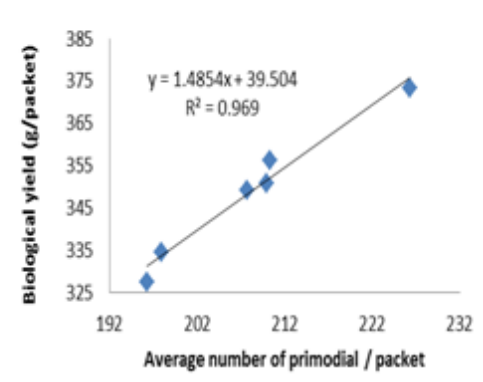

Fig. 3. Functional relationship between average numbers of primodia/packet and biological yield as influenced by different sawdust substrates

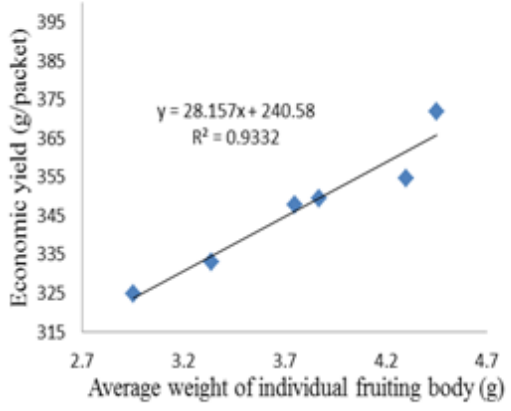

Fig. 4. Functional relationship between average weights of individual fruiting body and economical yield of oyster mushroom influenced by different sawdust substrates.

\section{CONCLUSION}

Oyster mushroom presents a promising potential for treatment of sawdast waste those generated in the saw mill. Different saw dust substrates such as Ficus carica (Fig tree, $\mathbf{T}_{\mathbf{2}}$ ), Albizia saman (Rain Tree, $\mathbf{T}_{\mathbf{3}}$ ), Swietenia mahagoni (Mahogany tree, $\mathbf{T}_{\mathbf{4}}$ ), Leucaena leucocephala (Ipil ipil tree, $\mathbf{T}_{5}$ ), Eucalyptus globulus (Eucalyptus tree, $\mathbf{T}_{\mathbf{6}}$ ) and mixture of all five tree sawdust $\left(\mathbf{T}_{\mathbf{1}}\right)$ supplemented with $30 \%$ wheat bran and $1 \%$ lime as basal substrates were ccultivate $P$. ostreatus mushroom. Since they were increased the mushroom yield and those sawdust substrate is better mushroom substrate compare to the previous scientist research work. It may also offer economic incentives for agribusiness to examine these residues as valuable resources and develop new enterprises to use them to produce nutritious mushroom products. Therefore, the mushroom cultivation may become one of the most profitable agribusiness that could produce food products from different substrates and help to dispose them in an environment friendly manner. Among all aspects, $\mathbf{T}_{\mathbf{3}}$ was found as a best substrate with biological yield (373.4 g/packet) and BE (213.2\%) followed by $\mathbf{T}_{\mathbf{1}}, \mathbf{T}_{\mathbf{4}}, \mathbf{T}_{\mathbf{6}}, \mathbf{T}_{\mathbf{5}}, \mathbf{T}_{\mathbf{2}}$ for the production of mushroom.

\section{Acknowledgements}

National Mushroom Development and Extension Center (NAMDEC) laboratory Savar, Dhaka, Bangladesh is gratefully acknowledged for their kind cooperation regarding the supply the fruiting body of oyster mushroom .I would like to gratefully acknowledged Mushroom Culture House (MCH), Biochemistry laboratory of the Department of Biochemistry, Sher-e-Bangla Agricultural University, Dhaka, Bangladesh for financial support my M.Sc. research work.

\section{REFERENCES}

[1] V. P. Mane, S. S. Patil, A. A. Syed, M. M. V. Baig, Bioconversion of low quality lignocellulosic agricultural waste into edible protein by Pleurotus sajor-caju (Fr.) Singer. Journal of Zhejiang University of Science, 8(10), 2007, 745-751.

[2] S. M. R. Amin, C. S. Nirod, M. Moonmoon, J. Khandaker, M. Rahman, Officer's Training Manual (National Mushroom Development and Extension Centre, Savar, Dhaka, Bangladesh, 2007) 7-17.

[3] L. Pathmashini, V. Arulnandh, R. S. W. Wijerathan, Efficancy of different spawn types on sawdust media (Tropical Agricultural research and Extension, 2008) 11.

[4] F. Zadrazil, F. Brunnert, Investigation of physical parameters important for the solid state fermentation of straw by white rot fungi. Eur. J. Appl. Microbiol. Biotechnol., 11, 1981, 183-188.

[5] C. L. Jandaik, S. P. Goyal, Farm and farming of oyster mushroom (Pleurotus spp) (In; Singh and Chaube (eds) Mushroom Production Technology. G. B. Pant Univ. Agri. and Tech., Pantnagar, India. 1995) 72-78.

[6] U. Kues, Y. Liu, Fruiting body production in basidiomycetes, Appl. Microbiol Biotec, 54, 2000, 141-152.

[7] T. Kausar, Cultivation of mushrooms using crop residues as substrate, Ph.D. Thesis. Department of Botany, University of Punjab, Lahore, Pakistan, 1988.

[8] S. T. Chang, P. G. Miles, Edible Mushroom and their cultivation (CRC press, Inc. Boca Raton, Florida U.S.A. 1988) 27: 83-88.

[9] Z. A. Shah, M. Ashraf and Ch. Ishtiq, Comparative study on cultivation and yield performance of oyster mushroom (Pleurotus ostreatus) on different substrates (Wheat straw, Leaves, saw dust). Pak. J. Nutri., 3, 2004, 158-160.

[10] E. Baysal, H. Peker, M. Kemal, A. Temiz, Cultivation of oyster mushroom on waster paper with some added supplementary materials, Bioresour. Technol., 89, 2003, 95-97.

[11] K. Thakur, S. R. Sharma, Substrate and supplementation for the cultivation of shiitake, Lentinus edodes (Berk.) Sing. Mush. Information. 9, 1992, 7-10.

[12] A. N. Shukla, Effect of hormones on the production of shiitake, Lentinus edodes (Berk.) Sing. Mushroom Res., 4, 1995, 3942.

[13] S. R. Sharma, S. Kumar, V. P. Sharma, Physiological Requirement for Cultivation of Malaysian Strain of Shiitake mushroom, J. Mycology. Plant. Pathol., 36(2), 2006, 149-152.

[14] M. W. Miller, S. C. Jong, Commercial cultivation of shiitake in sawdust filled plastic bags, Dev-Crop-Sci. Amsterdam: Elsevier Scientific Pub. Co., 10, 1987, 421-426. 
[15] A. A. Grodzinskaya, H. D. Infante, N. M. Piven, Cultivation of edible mushrooms using agricultural and industrial wastes, Agronomia- Tropical-Maracay, 52(4), 2003, 427-447.

[16] N. Caglarirmak, The nutrients of exotic mushrooms (Lentinula edodes and Pleurotus species) and an estimated approach to the volatile compounds, Food Chem., 105, 2007, 1188-1194.

[17] N. Bahl, Hand book on mushrooms (Oxford \& IBH Publishing co Pvt Ltd., 1998), Pp.15-40.

[18] A. Eswaran, R. Ramabadran, Studies on some physiological, cultural and post-harvest aspects of oyster mushroom, Pleurotus eous, Tropical Agricultural Research, 12, 2000, 360 - 374 .

[19] N. Das, M. Mukherjee, Cultivation of Pleurotus ostreatus on weed plants. Bio Resource Technology, 98, 2007, 2723 - 2726.

[20] A. Eswaran, R. Ramabadran, Studies on some physiological, cultural and post-harvest aspects of oyster mushroom, Pleurotus ostreatus, Tropical Agricultural Research Journal, 12, 2000, 360-374.

[21] A. M. Mshandete, J. Cuff, Cultivation of three types of indigenous wild edible mushrooms: Coprinus Cinereus, Pleurotus flabellatus and Volvariella volvocea on composted sisal decortications residue in Tanzania, Afr. J. Biotech., 7(24), 2008, 4551-4562.

[22] H. Sivrikaya L. Bacak A. Saacbasi, I. Toroguli, H. Erogulu, Trace elements in Pleurotus Sajor-caju cultivated on chemithermo mechenical pulp for bio-bleeching, Food Chem., 79, 2002, 173-176.

[23] S. T. Chang, Mushroom cultivation using the "ZERI" principle: potential for application in Brazil, Micologia Aplicada Internatonal, 19(2), 2007, 33-34.

[24] S. M. R. Amin, M. M. Rahman, M. M. Hossain, M. M. Haque, N. C. Sarker, Effect of Different Substrates on the Growth and Yield of Five Selected Oyster Mushrooms, Bangladesh J. Mushroom, 1 (2), 2007, 21-25.

[25] S. S. Patil, S. A. Ahmed, S. M. Telang, M. M. V. Bai, The Nutritional Value of Pleurotus Ostreatus (JACO.:FR) Kumm Cultivated on Different Ligocellulosic Agro-Wastes, Innovative Romanian Food Biotechnology, 7, 2010, 66-76.

[26] N. C. Sarker, M. M. Hossain. N. Sultana, H. Mian, A. J. M. S. Karim, S. M. R. Amin, Performance of Different Substrates on the Growth and Yield of Pleurotus ostreatus (Jacquin ex Fr.) Kummer, Bangladesh J. Mushroom, 1(2), 2007, 9-20.

[27] N. C. Sarker, Oyster mushroom (Pleurotus ostreatus) Production Technology Suitable for Bangladesh and its Nutritional and Postharvest Behavior, Ph.D. Thesis, Bangabandhu Sheikh Mujibur Rahman Agricultural University, Gazipur, Bangladesh, 2004.

[28] S. M. Ruhul Amin, Performance of different Oyster mushroom (Pleurotus spp) varieties, M.S. Thesis, Bangabundhu Sheikh Mujibur Rahman Agricultural University, Salna, Gazipur, 2002.

[29] S. Ahmed, Performance of differerent substrates on the growth and yield of Oyster mushroom (Pleurotus sajor-caju (Fr.) Sing), M.S. thesis, Institute of Postgraduate Studies in Agriculture, Salna, Gazipur, 1998.

[30] A. M. Khan, S. M. Khan, S. M. Khan, Studies on the cultivation of Oyster mushroom Pleurotus ostreatus on different substrates. Pakistan J. Phytopath., 13(2), 2001, 140-143.

[31] P. Kalita, N. Mazumder, P. Kalita, Performance of Oyster mushroom (Pleurotus spp.) on certain plant wastes. Horticultural Res. Stat. Assam Agricultural University, Assam, India. J. the Agricultural Sci., Society of North East India, 14(2), 2001, 221-224.

[32] D. J. Royse, Influence of spawn rate and commercial delayed release nutrient levels on Pleurotus cornucopiae (oyster mushroom) yield, size and time to production. Appl. Microbiol. Biotechnol., 58(4), 2002, 527-531.

[33] M. H. M. B. U. Bhuyan, Study on Preparation of Low Cost Spawn Packets for the Production of Oyster Mushroom (Pleurotus Ostreatus) and its Proximate Analysis, M.S. Thesis, Department of Biochemistry, SAU, Dhaka, 2008.

[34] A. K Patra, B. K. Pani, Yield response of different species of oyster mushroom (Pleurotus spp.) to paddy straw, Current Agril. Res., 8, 1995, 11-14

[35] R. A. Dhoke, R. A. Chavan, V. T. Jadhay, Cropping period and yield of Oyster mushroom (Pleurotus sajor-caju) on different agrosubstrate, Madras Agril. J., 88(4-6), 2001, 327-329.

[36] R. C. Dey, Mycelial Growth and Oyster Mushroom Production with Different Hormone and Media Composition, M. S. Thesis, Department of Biotechnology, BAU, Mymensingh, 2006.

[37] N. Yoshida, T. Takahashi, T. Nagao, J. Chen, Effect of edible mushroom (Pleurotus ostreatus) cultivation on in vitro digestibility of wheat straw and sawdust substrate, J. Japanese Soc. Grassland Sci., 39(2), 1993, 177-182.

[38] M. A. Habib, Comperative study on cultivation and yield Performance of Oyster Mushroom (Pleurotus ostreatus) on different substrates, M. S. Thesis, Department of Biotechnology, BAU, Mymensingh, 2005.

[39] A. K. Chowdhury, B. N. Panja, S. K. Laha, Organic supplements for better yield of oyster mushroom, J. Interacademicia B. C. K. V., India. 2(1-2), 1998, 116-117.

[40] M. K. Biswas, C. S. Shukla, S. M. Kumar, Method for increasing biological efficiency of Oyster mushroom (Pleurotus florida ) in Madhya Pradesh, Adv. Plant Sci., Indira Gandhi Argil. Univ., India. 10 (1), 1997, 69-74.

[41] S. Patrabansh, R. Madan, Mineral content of the fruiting bodies of Pleurotus sajor-caju (Fr.) Singer cultivated on different kinds of Biomass, Acta Blotechnologica India, 19 (2), 1997, 101-109.

[42] M. Obodai, C. Okine, K. A. Vowotor, Comparative study on the growth and yield of Pleurotus ostreatus mushroom on different lignocellulosic by-products, Food Res. Inst. Accra, Ghana. J. Industrial Microbiology and Biotechnology, 30 (3), 2003, 146-149. 